\title{
Agricultural intensification and risk in water-constrained hard-rock regions: a social-ecological systems study of horticulture cultivation in western India
}

\author{
Pooja Prasad $^{1}$ and Milind Sohoni ${ }^{1}$
}

\begin{abstract}
Developing countries frequently find their poverty reduction initiatives to be at odds with promotion of sustainable practices. In India too, agricultural intensification through horticulture cultivation is an important government strategy to raise farm incomes but its mechanisms and implications have not been critically analyzed. Our objective is to characterize this intensification and explore conditions under which its goals may be achieved while ensuring equity in access to ecological services and resilience of the social-ecological system (SES). Our focal SES is the water-constrained farm system of western India that overlays shallow hard-rock aquifers common to the Indian peninsula. We document farm decisions and coping strategies of 121 farmers over two consecutive years: a drought year and a good rainfall year. We find that farmers are driven to high-value horticulture to remain economically viable in the face of increasing social-ecological vulnerability due to factors such as monsoon variability, high groundwater development, and uncertainty in irrigation access. Through systems modeling, we uncover the feedback loops that propagate risk. Risk in access to water, in part due to monsoon dry spells, starts a cycle of expensive investments often requiring large loans to assure access and a simultaneous move to horticulture in response to the elevated cost of water. This mitigates risk for the farmer in the short run but, in the absence of regulation and complete information about the common groundwater pool, leads to competitive investments, driving the regime to greater uncertainty levels for the entire community. This vicious cycle of investment and intensification escalates risk, leading to frequent crop failure, farmer indebtedness, and the tragedy of the commons. Government interventions further catalyze this. We propose alternate leverage points to enhance social comprehension of risk and facilitate collective action so as to negotiate room for human needs while remaining within biophysical boundaries.
\end{abstract}

Key Words: agricultural intensification; common pool resource; development; groundwater management; horticulture; India; sustainable intensification; system dynamics

\section{INTRODUCTION}

The farming sector in India is marked by low productivity and poor returns but increasingly, it also faces large variability because of factors such as climate change, degradation of natural resources, and inefficient markets. This has given rise to widespread farmer distress in the country (Reddy and Mishra 2010, Nadkarni 2018, Shankari 2018, Suthar 2018). Many government initiatives aim to address this growing crisis. Promotion of agricultural intensification by shifting from foodgrain to high-value horticulture cultivation is one of them (Chand 2017, GoI 2017a). Between 2000-2001 and 2012-2013, India witnessed an increase in gross cropped area (GCA) under horticulture crops by $44 \%$, with the result that horticulture production now exceeds food-grain production in the country (GoI 2017b, c). Moreover, fruits and vegetables are grown disproportionately more by marginal $(<1 \mathrm{ha})$ and smallholding (1-2 ha) farmers (GoI 2015). Given the social and ecological impact of horticulture cultivation reported in developing countries (Weinberger and Lumpkin 2007, Birthal et al. 2008, Aragona and Orr 2011, Shaver et al. 2015), there is a need to carefully assess this strategy.

Agricultural intensification refers to activities that aim to increase the productivity or profitability of a given tract of agricultural land (Rasmussen et al. 2018). This includes reducing fallow time, increasing input use, or changing crop type for greater return (Shaver et al. 2015, Rasmussen et al. 2018). Early economists attributed intensification to technical innovation driven by rising population density (Boserup 1965) and described it as a technology treadmill (Cochrane 1958), which farmers are forced to get on in order to stay viable or else face pressure to exit. "Induced intensification" suggests that intensification is moderated through socioeconomic, institutional, and biophysical factors that aggravate farmer vulnerability (Turner and Ali 1996, Vasavi 2009, Rasmussen et al. 2018). Through greater market integration (Scott 1976, Meyfroidt et al. 2018), intensification is seen as a reason for erosion of safety nets and polarization of material living standards (Turner and Ali 1996). In Ulrich Beck's risk society based on modern agricultural intensification, manufactured risk is the predominant product (Chatalova et al. 2016) and the distribution of this risk-financial, social, or ecological-forms the basis of social stratification. Ecological risk of intensification and monoculture is also a serious concern (Matson et al. 1997). An emerging paradigm is that of sustainable intensification, which addresses the interdependent goals of securing the environment and human well-being by operating within safe biophysical limits for a resilient earth system (Godfray and Garnett 2014, Pretty and Bharucha 2014, Rockström et al. 2017).

In this work, we characterize the ongoing intensification in our study region and analyze its social-ecological impact. Our focus is the shift toward horticulture crops, primarily fruit and vegetables, through intensification of, among other inputs, water, and also frequently, reduction in fallow time. Our focal socialecological system (SES) is the water-constrained shallow hardrock aquifer region of western India. These aquifers are predominant in peninsular India and, in general, play an important role in Asia and Africa where a large population depends upon them for livelihood and drinking water (Foster 
2012). Using the SES lens (Anderies et al. 2004, Binder et al. 2013, Stojanovic et al. 2016, Villholth et al. 2017, Rasmussen et al. 2018), we uncover the human-nature dynamics and analyze the role of biophysical factors, as mediated through existing social and institutional arrangements, in driving farm management decisions, which in turn dynamically impact natural resources. The analysis is based on farmer interviews and biophysical surveys conducted in two consecutive years: a drought year and a good rainfall year.

We show that farmers intensify to remain economically viable in the face of increasing social-ecological vulnerability because of factors such as monsoon variability, high groundwater development, and competitive private investments to assure irrigation often through large loans. Modeling of the SES dynamics shows that investments in water and intensification appear helpful in mitigating risk for individual farmers in the short run, but reinforce risk for the community as a whole by increasing stress on the limited common pool resource (CPR). This creates a vicious cycle in which other farmers are induced to invest and intensify in order to stay viable, thereby leading to the tragedy of the commons. This pushes the system toward greater risk for everyone as evidenced in the high rates of crop failures, farmer indebtedness, and poor access to ecological services especially for the asset-poor and the landless. Evaluation of leverage points (Meadows 1999) shows that government programs further catalyze this process leading to intensification beyond the system's carrying capacity. We propose alternate leverage points that pave the pathway to sustainable intensification through explicit recognition of the biophysical boundaries and their translation to farm level intensification.

\section{STUDY AREA AND METHODOLOGY}

\section{Study area}

Our study is in the Sinnar block, Nashik district, of Maharashtra state (Fig. 1, Appendix 1). Nashik is one of the highest vegetable and fruit producing districts in India. Peninsular India's largest river Godavari originates here, contributing to Nashik's history of early intensification. The district is known to have a progressive farming community that is quick to adopt new technology and farming practices. There exists a strong network of agents (Aga 2018), both public and private, and access to markets that drive a thriving agricultural economy.

Sinnar block was selected because it is currently undergoing intensification with $65 \%$ of cultivable area still under food-grain cultivation. Rainfall varies significantly $(200-700 \mathrm{~mm})$ both yearto-year and within a season (Appendix 2). Using a GIS-based analysis, four villages within the block were selected so as to cover different agro-climatic, watershed, and social attributes (Table 1). These are the relatively water-rich Pandhurli and Wadgaon Sinnar, and the drought prone Dapur and Dodhi Kh.

\section{Biophysical regime}

The hydrological year begins in June, when the monsoon breaks (Fig. 2). Kharif (monsoon) is the main cropping season, followed by the Rabi (winter) and summer season. Additionally, there are multiyear crops such as fruit orchards. An increasingly important feature of the climate is long dry spells during monsoons (Singh et al. 2014), and the need for protective irrigation for the monsoon crop. Postmonsoon crops depend upon residual soil moisture or
Fig. 1. Field location: villages selected for field work in Sinnar block, Nashik district of Maharashtra state in western India.

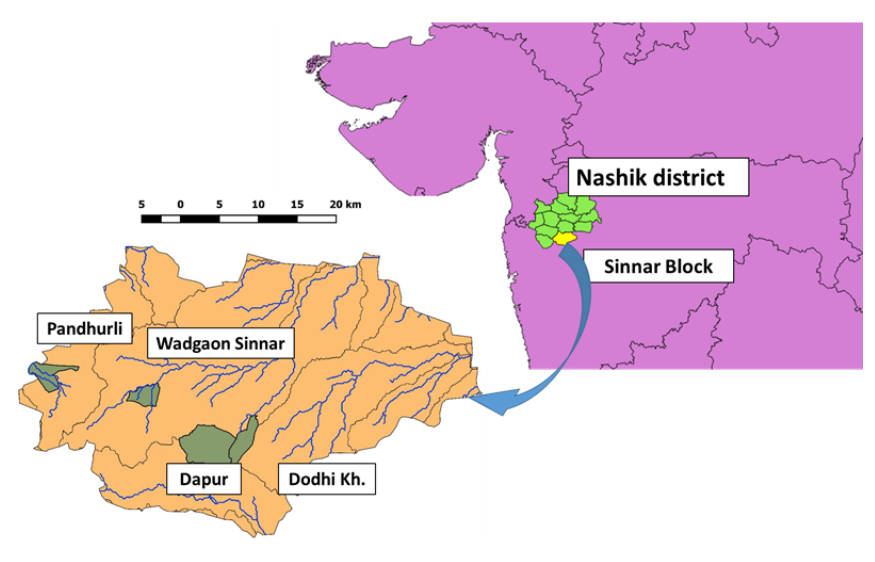

Fig. 2. Stylized representation of groundwater and cropping cycle in field area. Groundwater level rises due to recharge from monsoon rainfall between June to October. In shallow aquifers, open-dug wells are the most common tools of extraction. Well recharge rate varies based on biophysical factors. This period corresponds to the Kharif (monsoon) crop. If there is a long dry spell in the season, wells may or may not have sufficient water to protect the crop. Postmonsoon Rabi (winter) and summer season crops require irrigation. Well levels start to drop because of groundwater extraction and partly because of subsurface flows. Farmers may transfer water between multiple wells that they own through pipelines to increase months of irrigation access, e.g., combine water from well 1 and well 2. Well levels are low in summer and summer crop is cultivable only in a few groundwater rich pockets. Poor rainfall or excessive extraction lead to long periods of dry wells until monsoon arrives again in the following year.

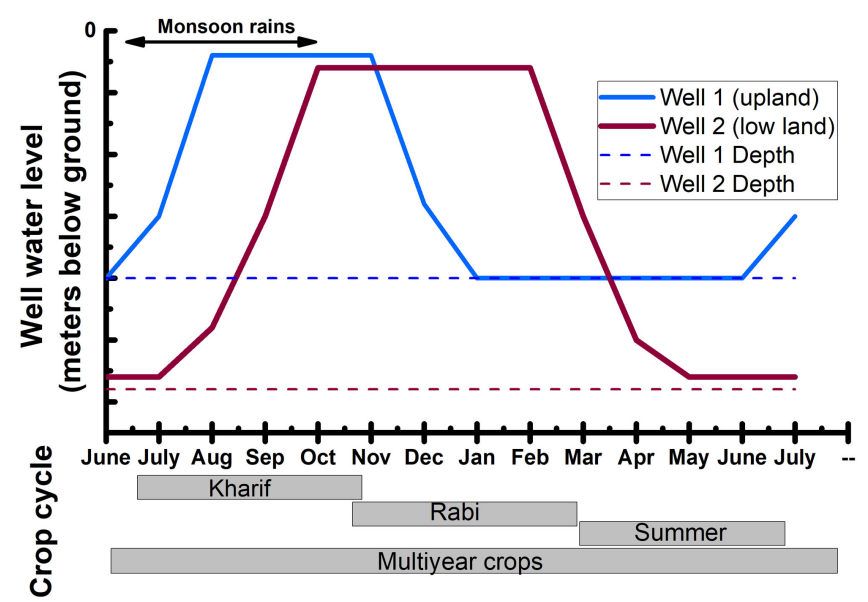


Table 1. Attributes of selected villages.

\begin{tabular}{|c|c|c|c|c|}
\hline & Dodhi Kh & Dapur & Wadgaon Sinnar & Pandhurli \\
\hline \multirow[t]{3}{*}{$\overline{\text { Demographic data }^{\dagger}}$} & Population: 1893 & Population: 5902 & Population: 2722 & Population: 4447 \\
\hline & Households: 319 & Households: 1066 & Households: 466 & Households: 826 \\
\hline & SC: $8 \% ;$ ST: $14 \%$ & SC: $3 \% ;$ ST: $16 \%$ & SC: $9 \% ;$ ST: $30 \%$ & SC: $23 \% ;$ ST: $26 \%$ \\
\hline Village Geographical Area (ha) & 1089 & 2985 & 815 & 1040 \\
\hline Village Cultivable Area (ha) & 834 & 1320 & 693 & 866 \\
\hline Mean Elevation (m) & 670 & 720 & 692 & 588 \\
\hline 2015 Rainfall $(\mathrm{mm})^{*}$ & 472.1 & 472.1 & 503.4 & 717.5 \\
\hline 2016 Rainfall $(\mathrm{mm})^{*}$ & 563 & 563 & 739 & 899.5 \\
\hline $\begin{array}{l}2015 \text { government tankers for } \\
\text { drinking water? }\end{array}$ & Yes & Yes & Requested but not received & No \\
\hline $\begin{array}{l}2016 \text { government tankers for } \\
\text { drinking water? }\end{array}$ & No & No & No & No \\
\hline Dominant soil type & $\begin{array}{l}\text { Sandy loamy in southern } \\
\text { part and clayey soil in } \\
\text { northern part }\end{array}$ & Sandy loamy & $\begin{array}{l}\text { Predominantly black clayey } \\
\text { soil except gravelly clay close } \\
\text { to stream and hills }\end{array}$ & $\begin{array}{l}\text { Predominantly black clayey } \\
\text { soil except gravelly clay close } \\
\text { to stream and hills }\end{array}$ \\
\hline Surface water source & $\begin{array}{l}\text { Part of village in Bhojapur } \\
\text { canal command area }\end{array}$ & $\begin{array}{l}\text { Private group lift irrigation } \\
\text { schemes }\end{array}$ & $\begin{array}{l}\text { Seasonal Devnadi River and } \\
\text { diversion-based irrigation } \\
\text { system in part of village }\end{array}$ & $\begin{array}{l}\text { Darna River with year-round } \\
\text { water due to release from } \\
\text { upstream dam }\end{array}$ \\
\hline Main Kharif crops & Pearl millet, onion & $\begin{array}{l}\text { Peal millet, onions, tomatoes, } \\
\text { and other vegetables }\end{array}$ & $\begin{array}{l}\text { Soybean, tomato, and other } \\
\text { vegetables, maize }\end{array}$ & $\begin{array}{l}\text { Soybean, maize, paddy, } \\
\text { tomatoes, and other vegetables }\end{array}$ \\
\hline Main Rabi crops & Onions, green gram, wheat & Onion, green gram, wheat & $\begin{array}{l}\text { Onions, wheat, green gram, } \\
\text { vegetables }\end{array}$ & $\begin{array}{l}\text { Onions, wheat, maize, } \\
\text { vegetables }\end{array}$ \\
\hline Multiyear crops & Pomegranate & Pomegranate & Pomegranate, grapes & Pomegranate, grapes \\
\hline $\begin{array}{l}\text { Gross sown area as share of } \\
\text { cultivable area }(2015-16)\end{array}$ & $\begin{array}{l}\text { Kharif foodgrain: } 66 \% ; \\
\text { Soybean: } 3 \% \text {; Rabi } \\
\text { foodgrain: } 7 \% \\
\text { Onion: } 11 \% \text {; Vegetables: } 3 \% \text {; } \\
\text { Fruit orchards: } 2 \%\end{array}$ & $\begin{array}{l}\text { Kharif foodgrain: } 49 \% \text {; } \\
\text { Soybean: } 5 \% \text {; Rabi } \\
\text { foodgrain: } 15 \% \text {; Onion: } 6 \% \text {; } \\
\text { Vegetables: } 9 \% \text {; Fruit } \\
\text { orchards: } 15 \%\end{array}$ & $\begin{array}{l}\text { Kharif foodgrain: } 16 \% \\
\text { Soybean: } 32 \% \text {; Rabi } \\
\text { foodgrain: } 20 \% \text {; Onion: } 8 \% \text {; } \\
\text { Vegetables: } 27 \% \text {; Fruit } \\
\text { orchards: } 2 \%\end{array}$ & $\begin{array}{l}\text { Kharif foodgrain: } 22 \% \text {; } \\
\text { Soybean: } 59 \% \text {; Rabi } \\
\text { foodgrain: } 29 \% \text {; Onion: } 14 \% \text {; } \\
\text { Vegetables: } 13 \% \text {; Fruit } \\
\text { orchards: } 10 \%\end{array}$ \\
\hline
\end{tabular}

irrigation by groundwater extraction or surface water transfers. The aquifer in Sinnar is shallow (10 m - $20 \mathrm{~m}$ deep) fractured basalt with moderate to poor yields (approximate specific yield of 0.02 ) and is accessed by shallow dug wells. A unique feature of these aquifers is that excessive extraction, instead of leading to a continually dropping water table, has a temporal effect. It causes longer periods of dry wells before the next monsoons arrive and recharge the groundwater (Foster 2012, Shah 2012). There is also significant spatial variation, and some water-rich pockets (for, e.g., in stream proximity) have substantially larger yield. Sinnar is classified as "semicritical" in terms of groundwater development (GoI 2014a).

\section{Social agents}

The field area is dominated by smallholding farmers belonging to the Vanjari community, a traditionally nomadic community now settled in the region for many generations. Other communities include the Marathas (the traditional farming community) and the scheduled caste and tribes. These caste differences are known to play out in the landholding size and location as well as in access to social networks and institutions. The literacy rate $(82 \%$ in GoI $2014 b)$ is higher than the national average $(74 \%)$ and more than a third of agricultural households have a supplementary nonfarm income. Farmers draw upon their social network for information on latest technology, practices, and markets. State knowledge extension service is limited. The main institutions for groundwater monitoring, the central ground water board (CGWB) and the state groundwater surveys and development agency (GSDA), have poor capacity to enable strong governance (Kulkarni et al. 2015, Shah 2016). A large number of private actors are involved in provision of inputs, tools, knowledge (Aga 2018) and postharvest support. There are notable interventions from nongovernmental organizations in watershed treatment and livelihood generation. In general, farmers vary not only in their access to biophysical resources depending upon location and quality of their farm lands but also in their access to social networks and institutions, which together impact their decisions and risk taking ability.

\section{Data collection}

A detailed ethnographic and biophysical study was conducted (Fig. 3). Across four villages, 121 farmers were interviewed in the first phase (between February and August 2016) in the drought year of 2015-2016. Stratified random selection was used to select farms on the village cadastral map to cover different geographical regions of the village. An effort was also made to stay close to village landholding size distribution in the sample and to ensure that all landholding communities were represented (Appendix 3). Farm biophysical attributes, socioeconomic data, history of agricultural practice, and information on farmer aspirations were collected. A second phase of interviews (between February and April 2017) was conducted when 88 of the original 121 farmers were revisited in the following good rainfall year 2016-2017.

\section{FINDINGS}

\section{Crop intensification hierarchy}

We observed that there is a regional intensification hierarchy of crops ordered by season and expected financial returns that is central to farmers' decision making. Nonperishable crops such as pearl millet, sorghum, pigeon pea, and gram are low-risk and low- 
Fig. 3. Data collection and field work activities.

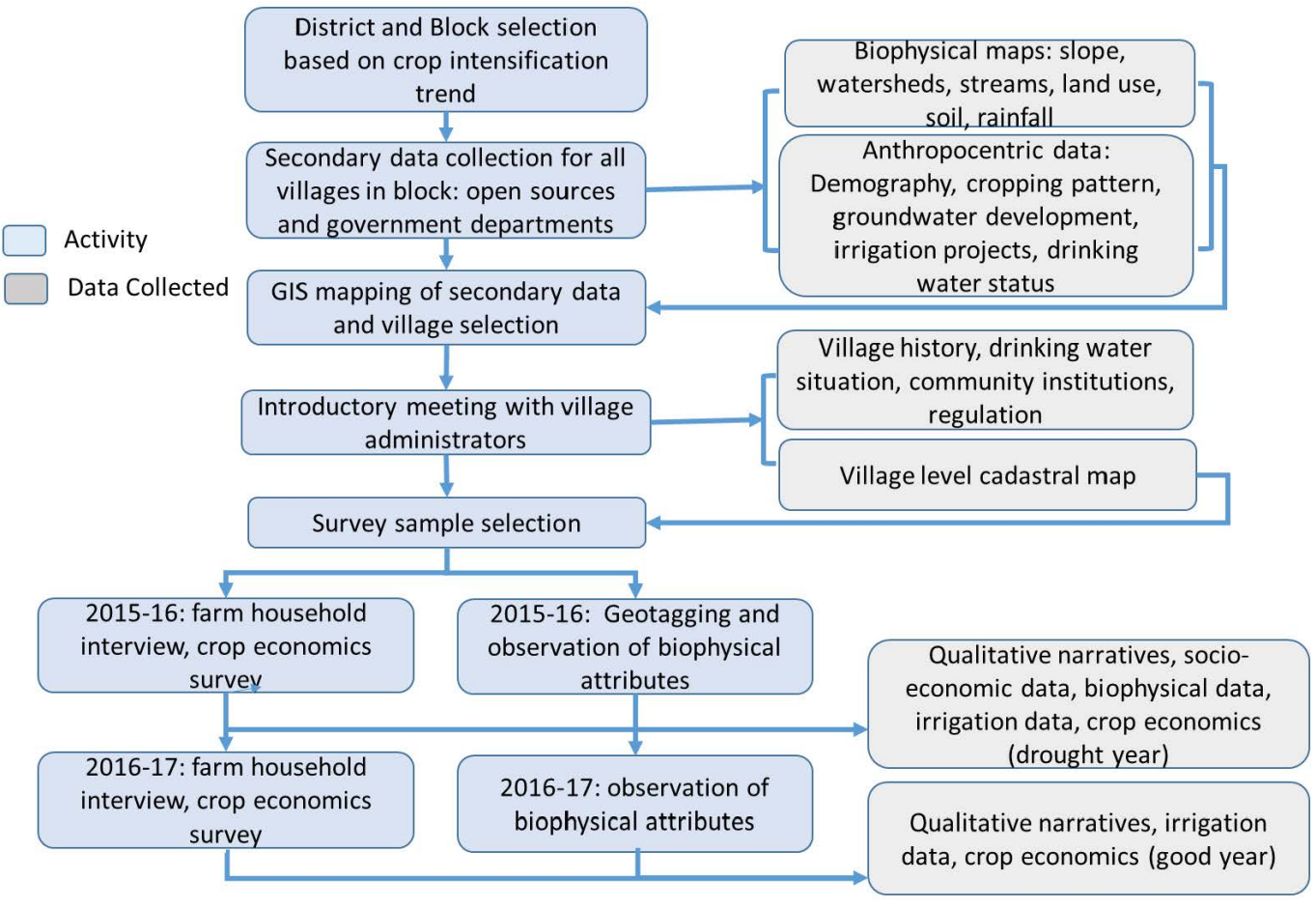

reward. They require little investment, are drought resistant, and also useful as fodder. Farmers consume part of the production and sell the surplus. Soybean, groundnut, and maize are nonperishable cash crops that are more input intensive but offer better market returns. Next are the short-duration green leafy vegetables such as cilantro, fenugreek, spring onions, that are popular amongst smallholding farmers. They are considered a gamble, but with relatively low downside and may be cultivated multiple times within a season. Cultivation of vegetables such as tomatoes, cabbage, cauliflowers, and broccoli requires far more inputs, knowledge, and precise irrigation schedule, and is prone to high market risk. They are thus grown by farmers who can invest in irrigation infrastructure and withstand losses. At the top of the hierarchy are multiyear orchards. These require large investments, access to special markets, and availability of water buffers to assure year-round irrigation. It is farmers with relatively high access to capital, water, and risk-bearing ability who invest in orchards.

We found that those who operate higher up in the intensification hierarchy not only have greater expected returns but also greater (a) cost of cultivation, (b) crop water requirement, both in quantity and frequency of irrigations, and importantly, (c) variability in yields and returns (Fig. 4). The high variability in yield is not a direct corollary of intensification but instead is mediated through the variability of inputs such as water. The variability in market prices is seen in two forms (Appendix 4): seasonal variation of daily modal market prices and price spread within a day due to disparity in produce quality partly attributable to irrigation shortfall. Together they result in high variation in profitability. For instance, even though the average return on Rabi onions was found to be at least 2.5 times that for nonhorticulture crops, $30 \%$ of onion farmers made losses or just broke even (Fig. 4D).

\section{Farmer decisions}

We found that every year farmers take three key steps, consciously or subconsciously, influenced by a variety of socioeconomic factors and institutions. These steps are to (a) decide the seasonal cropping pattern, (b) prepare an informal irrigation plan, and (c) decide on any investments for enhancing water access.

First is the seasonal decision of which crop to sow and how much. This is informed by the crop intensification hierarchy and socioeconomic considerations such as access to capital, family labor, and peer-influence (Stone 2007). All the same, a crucial factor is the farmers' estimate of available water for that year and the perceived ability to meet crop water requirements. A good rainfall year allows for a higher sown area and reduced fallow (see Appendix 5). Farmers' success depends vitally on the soundness of this estimate.

Second, farmers make an informal irrigation plan for their chosen crop portfolio. Depending on their estimate of available water, farmers devote part of their land to high-value crops with the goal of meeting its complete water requirement. The remaining land is used to cultivate low-water intensity crops or left fallow. This is contrary to the traditional practice of protective irrigation in drought-prone areas (Jurriëns et al. 1996). However, farmers often go wrong in their estimate and fall short of water. When this happens, they prioritize the crop highest in the intensification hierarchy at the expense of other crops. Onion is allowed to fail to save water for pomegranate and wheat is sacrificed to irrigate 
Fig. 4. Seasonal crop intensification hierarchy and farm economics. Key economic attributes of main Kharif (monsoon), Rabi (winter), and summer crops. (A) Input cost; (B) Irrigation events: number of times that the crop was irrigated during the crop duration for seasonal crops or through a year for multiyear crops. All crops except fruit orchards and a share of tomato crops are irrigated using flood irrigation. (C) Crop yield in quintal/hectare; (D) Profit per hectare (E) Return from water (in Rupees per cubic meter of water required by crop). As farmers shift their cropping pattern along the hierarchy toward horticulture crops, they face significantly higher input costs and need for irrigation. Farmers vary in their ability to fully irrigate their crop, which contributes to high variation in crop yields and hence, farm returns. Though average returns increase as farmers intensify along the crop hierarchy, it can be seen that a significant share of horticulture farmers faces crop failure. The high return per unit water for horticulture crops explains large investment in water infrastructure. Volume of data-points for different crops varies because it depends upon number of farmers who cultivated each crop in the survey year. Data is for year 2015-2016 based on surveys of sampled farmers. Survey data for 2016-2017 was not used for this analysis because an extraordinary external event of national currency demonetization in Nov 2016 resulted in severe market distortion. ** Yield for green-leafy vegetables unavailable because they are not sold by weight but in nonstandard sized "bundles."

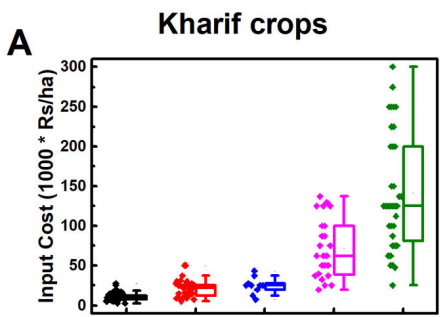

B
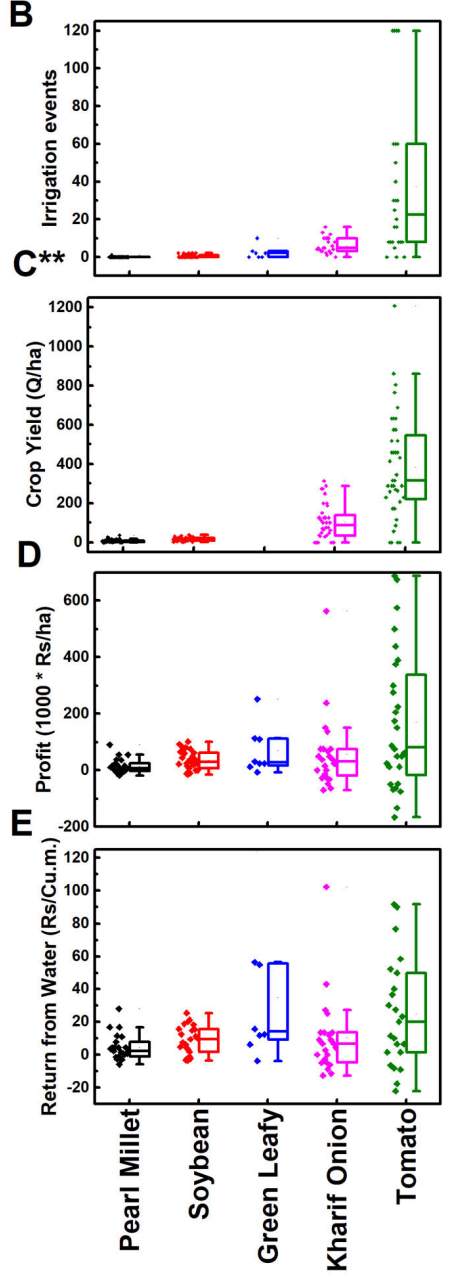
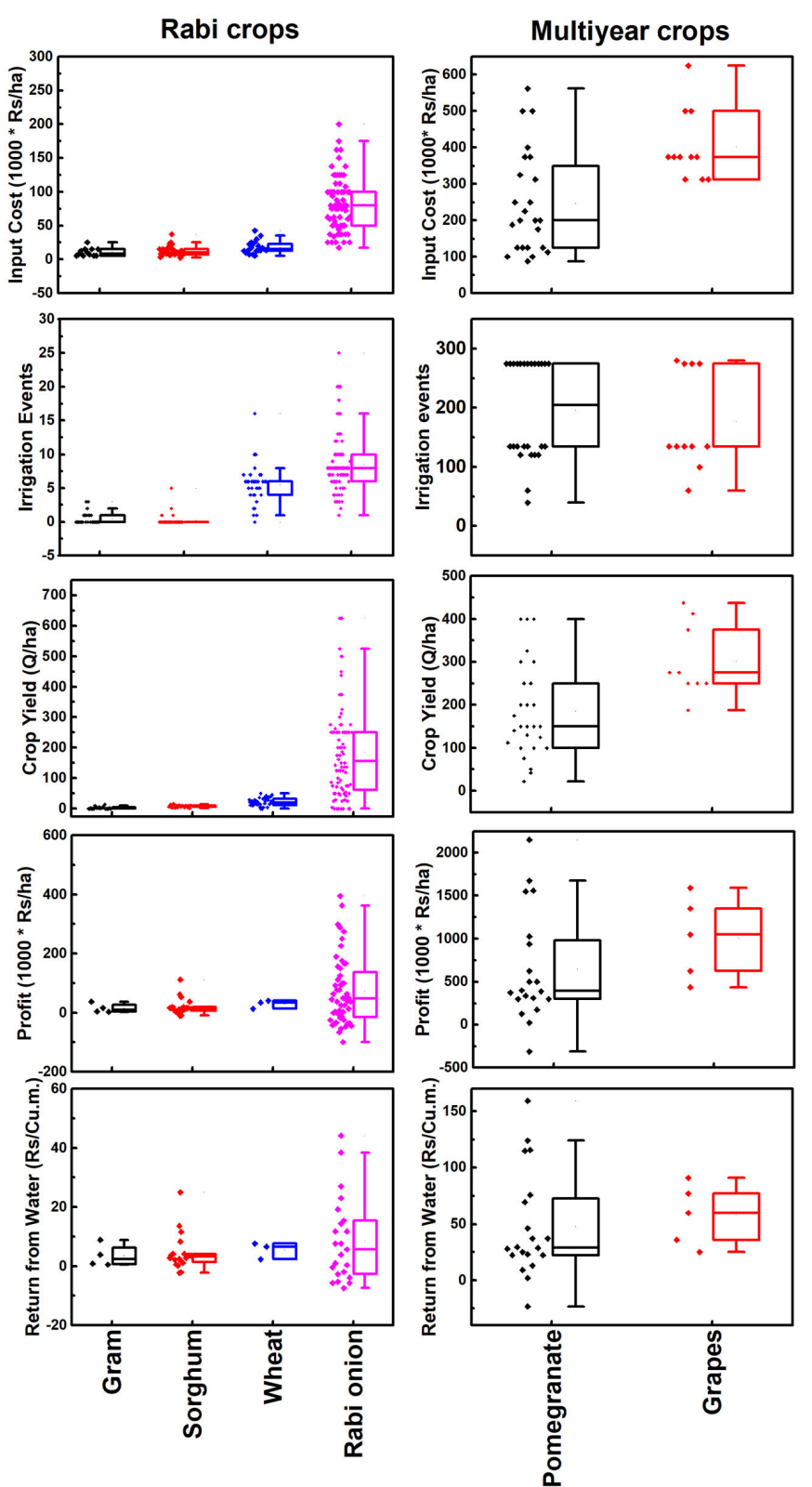
Table 2. Summary of investments in water infrastructure, high-value horticulture cultivation, and outcomes.

\begin{tabular}{|c|c|c|c|c|c|c|c|c|c|c|}
\hline \multirow[b]{2}{*}{ Village } & \multirow[b]{2}{*}{$\begin{array}{l}\text { Number } \\
\text { of } \\
\text { surveyed } \\
\text { farmers }\end{array}$} & \multicolumn{4}{|c|}{ Private investments in water } & \multicolumn{2}{|c|}{ High-value crop choice } & \multicolumn{3}{|c|}{ Failures and risk } \\
\hline & & $\begin{array}{l}\text { Farmers } \\
\text { with } \\
\text { lateral } \\
\text { bores in } \\
\text { well }\end{array}$ & $\begin{array}{l}\text { Farmers with } \\
\text { pipelines for } \\
\text { water transfer }\end{array}$ & $\begin{array}{c}\text { Farmers } \\
\text { with } \\
\text { farm- } \\
\text { ponds }\end{array}$ & $\begin{array}{c}\text { Farmers who } \\
\text { purchased } \\
\text { water tanker } \\
\text { for irrigation }\end{array}$ & $\begin{array}{c}\text { Farmers } \\
\text { cultivating } \\
\text { high value } \\
\text { horticulture }^{\dagger}\end{array}$ & $\begin{array}{c}\text { Farmers } \\
\text { with } \\
\text { orchard }\end{array}$ & $\begin{array}{l}\text { Farmers with } \\
\text { primary crop } \\
\text { failure during } \\
\text { survey years }\end{array}$ & $\begin{array}{c}\text { Farmers } \\
\text { who } \\
\text { deintensified }\end{array}$ & $\begin{array}{c}\text { Farmers with } \\
\text { unpaid } \\
\text { pending farm } \\
\text { loans }\end{array}$ \\
\hline Pandhurli & 18 & $33 \%$ & $28 \%$ & $0 \%$ & $0 \%$ & $83 \%$ & $11 \%$ & $33 \%$ & $17 \%$ & $17 \%$ \\
\hline Wadgaon Sinnar & 34 & $50 \%$ & $35 \%$ & $12 \%$ & $26 \%$ & $71 \%$ & $24 \%$ & $29 \%$ & $21 \%$ & $18 \%$ \\
\hline Dapur & 33 & $39 \%$ & $58 \%$ & $15 \%$ & $27 \%$ & $76 \%$ & $52 \%$ & $55 \%$ & $6 \%$ & $39 \%$ \\
\hline Dodhi Kh. & 36 & $44 \%$ & $8 \%$ & $11 \%$ & $28 \%$ & $36 \%$ & $17 \%$ & $56 \%$ & $28 \%$ & $36 \%$ \\
\hline
\end{tabular}

Short-duration green leafy vegetables are not considered high value for the purpose of this table because of their high popularity.

onions. Sorghum and gram are likely to remain unirrigated. At the top of the hierarchy, fruit orchards almost always get full irrigation even if through purchased tanker water. Thus, the portfolio of crops results in a combination of a fixed crop water requirement load that the farmer fulfills against all odds, and a variable requirement that is fulfilled whenever possible.

Third, because crop failures due to shortage of irrigation are frequent, farmers often re-evaluate their cropping pattern and water access. As a result, they may decide to make investments to reduce future risk, primarily in water infrastructure but also in new knowledge or technology. This is accompanied by a structural shift in the cropping pattern to a higher band of operation within the intensification hierarchy in order to recover the investment. The decision is also influenced by the farmer's socioeconomic situation and ongoing life events, and in some cases, the farmer may instead step back and deintensify. These practices are evidenced in the farmers' narratives (Appendix 6).

\section{Water access}

Groundwater is the most important resource that enables irrigation in the region and is accessed primarily through private means. Farmers use three observable attributes to describe their groundwater access: (a) access device and modalities of use, e.g., shared or personal well, pumps, pipelines, (b) amount of water available in terms of maximum hours of pumping before the well is emptied and the time to recovery of the water level, e.g., daily 4 hours of pumping in February using a standard 5 HP pump, and (c) months of water available after which water level does not recover sufficiently for irrigation use. For most farmers, these attributes decide if they can cultivate a postmonsoon crop. However, there is variation in the amount and period of available water from one year to another because of variability in the monsoon pattern and changes in groundwater extraction patterns in the larger community. Hence, these attributes change dynamically and are prone to misjudgments.

In addition to this, many farmers find ways, formal and informal, of enhancing water access, with financial as well as politicalmediation costs. Farmers often have access to multiple wells on fragmented farmlands between which water is transferred through private pipelines (Fig. 5). Lateral bores are made radially outwards in all directions to direct groundwater flow into wells. Patches of land just large enough to dig a well are bought next to streams and reservoirs from which water is piped over many kilometers. The most instructive of all investments is the plastic- lined farm-pond to overcome temporal uncertainty in water. Groundwater is pumped into farm-ponds in monsoon and stored for use in summer. Almost half of this precious groundwater is lost to evaporation during storage (Kale 2017), yet there is high demand for such ponds because whatever water remains helps to meet the demand for assured irrigation during scarcity months. Moreover, government subsidy is available to build these. Importantly, between the two years of survey, close to $10 \%$ of sampled farmers constructed new farm-ponds, largely in the two most drought-affected villages, either in response to crop failures or to enable intensification.

Fig. 5. Farmer investments in water. (a) Number of wells per farmer and the well depth for surveyed farmers in the four villages. Most farmers have access to multiple wells, some of which are shared family wells. The majority are open-dug wells. The deeper ones are borewells, which are few in number and have low yields. (b) Distribution of months of water available for irrigation starting at the onset of monsoons: naturally through wells (W) and postenhancements (A). Pandhurli and Wadgaon Sinnar have relatively good access to water naturally that allows for cultivation in two seasons. There is, however, significant variation within the village depending upon biophysical factors. Dapur and Dodhi villages are highly water scarce. Enhancement in months of access by private investment in farm-ponds, pipelines to transfer water from wells in water rich zones, lift from surface water sources etc., result in an increase in months of water availability. Such investments are seen most in Dapur, followed by Dodhi village. The high cost of these investments induce farmers to intensify to high value crops but with greater risk compared to Pandhurli and Wadgaon farmers.
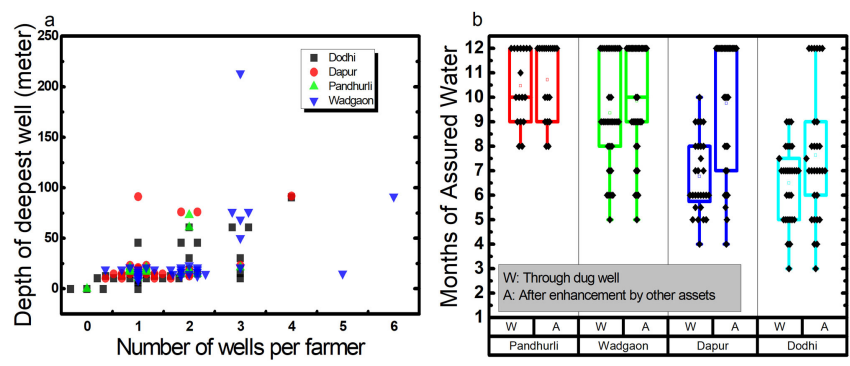
Fig. 6. Two tier causal-loop diagram showing (a) farmer level and (b) community level dynamics of farmer decision making in response to social-ecological risks mediated through existing social and institutional networks. The actions of investment and intensification, which appear as risk mitigating or balancing loops for individual farmers, emerge as risk reinforcing loops at the community level. "Investment to improve access" (balancing) loop at farmer level emerges as "competitive investment" (reinforcing) loop at community level when many farmers start investing in water infrastructure. Similarly, the "intensification for profitability" (balancing) loop at farmer level leads to "impact to common property resource" (reinforcing) loop as the aggregated irrigation requirement for the community increases with intensification. The worsening of community level attributes ("stage of groundwater development" and "aggregate investment in private water asset") in turn leads to higher risk for individual farmers resulting in a vicious cycle of investment and intensification, and as a result, greater farmer indebtedness. Farmers with poor social and institutional support are forced to deintensify and search for nonfarm employment. At the community level, there is rise in inequity in access to water and drinking water insecurity for those dependent on shallow public wells. Note that positive causality between two attributes (say, $\mathrm{x}$ and $\mathrm{y}$ ) implies that when all other factors are held constant, an increase in $\mathrm{x}$ causes an increase in $\mathrm{y}$ (or decrease in $\mathrm{x}$ leads to decrease in $\mathrm{y}$ ). Negative causality implies that increase in $\mathrm{x}$ causes a decrease in $\mathrm{y}$, all other factors being equal.
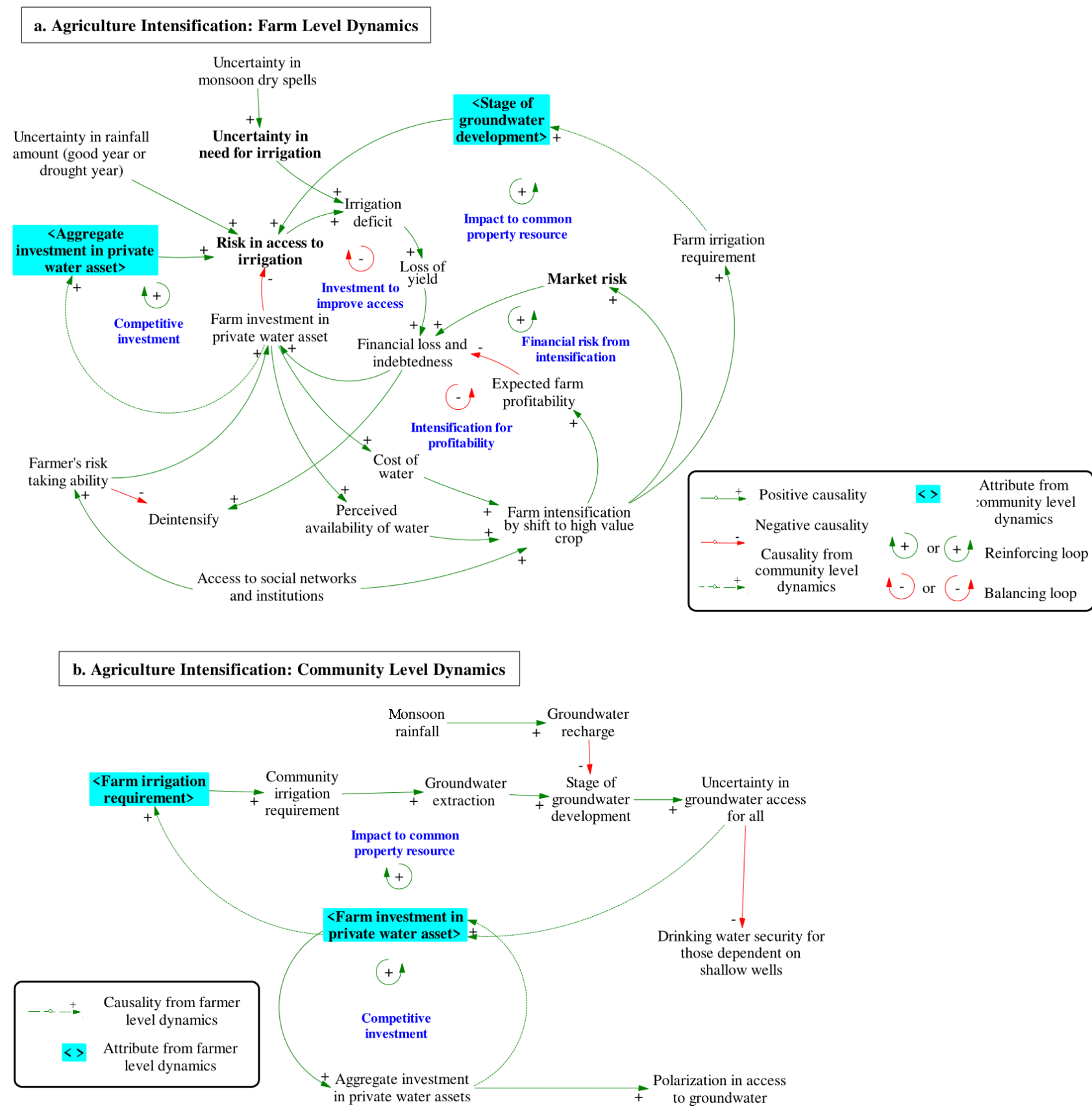
Fig. 7. What will stop the vicious cycles? Leverage points. Current interventions by the state are low leverage points. Watershed interventions increase groundwater recharge and promotion of microirrigation enhances water-use efficiency. But the perception of enhanced water availability due to these interventions continues to drive the cycle of intensification beyond sustainable levels. Government subsidies for new farm-ponds and orchards further contribute to this. Higher leverage points are those that will limit intensification and investments to a level within the social-ecological thresholds of the SES. Collective planning of seasonal intensification level based on a sound estimate of available water will reduce risk of crop failures due to irrigation shortage and build resilience to monsoon variability. This, as shown, will break the vicious cycle of impact to common property resource. A community plan for setting aside water for protective irrigation will reduce uncertainty during monsoon dry spells. Community regulation will stop the competitive investment and intensification for profitability loops, reduce failures and variability in returns. These interventions require coproduction of local science of water by scientists, state, and the community. An even higher leverage point, though long term, is to disrupt the crop hierarchy so that consumer choices are aligned with low water-footprint produce.
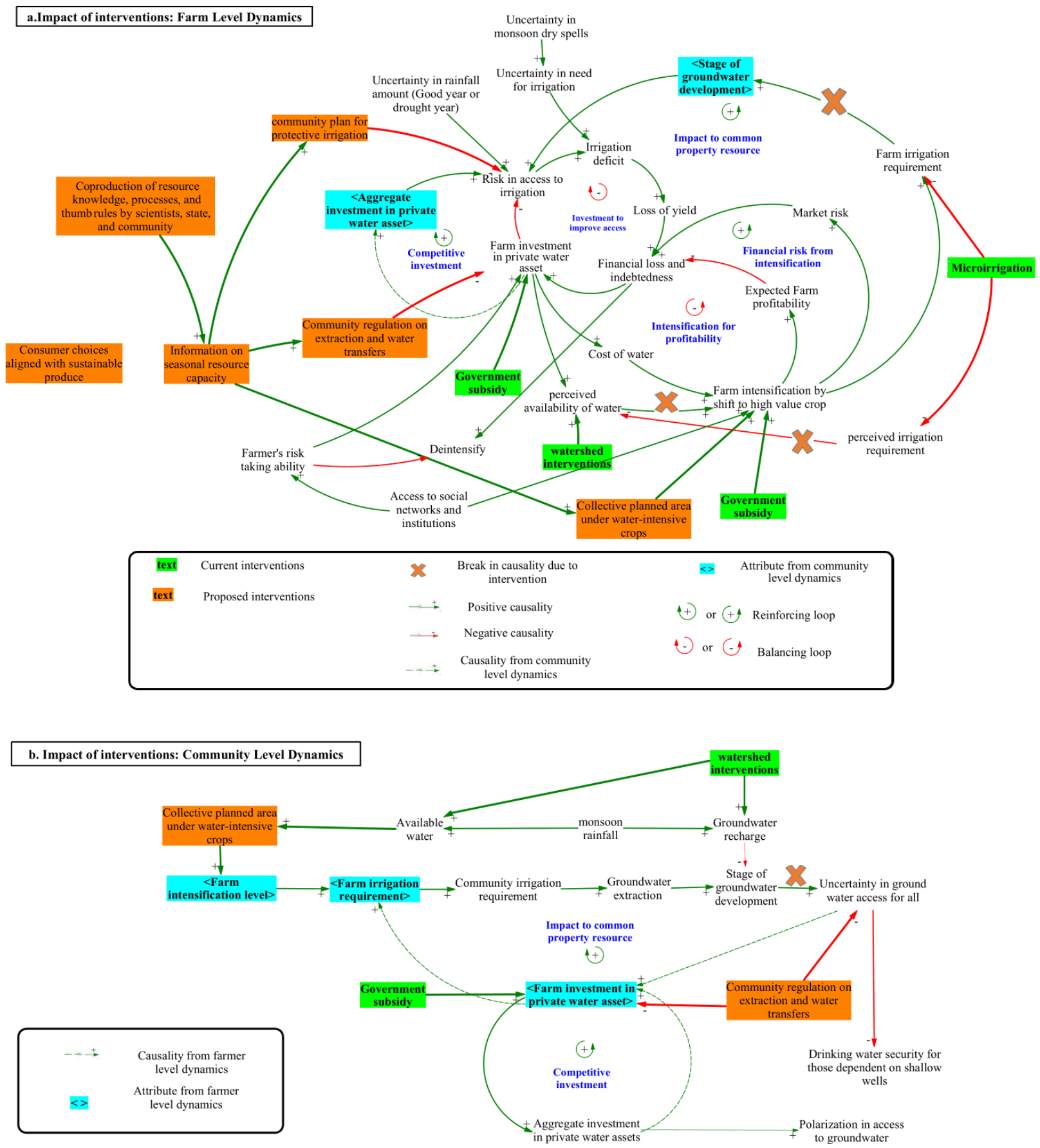
The net result is that the region is a mosaic of highly unequal access to groundwater, crisscrossed by a network of pipelines, and dotted with hundreds of farm-ponds. The more severe the water scarcity, the more are such investments. The changing configuration of interventions impacts groundwater flows creating variability in access and reinforcing the socioeconomic disparity within the community. The most vulnerable are the landless and those without wells who depend on shallow public wells and face seasonal drinking water scarcity, a recurrent feature of this SES. We thus find a situation where some irrigate orchards in summer while some others face drinking water stress.

In absence of explicit knowledge of the dynamic resource capacity and effective groundwater regulation or management, it is accepted that farmers have the right to extract any amount of water from wells on their own land (Shah 2013, Kulkarni et al. 2015, GoM 2018). In contrast, community regulation of surface water use is common, especially near drinking water sources. Its dynamics are visibly understood by all and there are regulatory instruments, which even when not applied, serve to define acceptable behavior.

\section{Village level picture}

Dodhi Kh. village is highly drought prone. It is historically known for its onion crop but after repeated failures farmers now either look for nonfarm opportunities or intensify by investing in pomegranate orchards and farm-ponds. Dapur is an equally drought prone village where farmers have made large investments in private group lift irrigation schemes over the past two decades. Ten to twenty farmers come together to purchase land and construct a well next to Bhojapur, a public irrigation reservoir, and lay pipelines over $10-15 \mathrm{~km}$ to bring this water to their farms. These are expensive, technically intricate systems at the cusp of surface-water and groundwater, and being in the gray area of regulation, need constant informal negotiations with different agencies. The initial success led to a plethora of such schemes, thereby increasing risk in water availability. Recognizing the diminishing assurance, many farmers made further investment in private farm-ponds to buffer water for use in summer. A direct consequence of this competition is that Dodhi Kh., which has a formal reservation on water from Bhojapur reservoir, does not get its full allocation, prompting farmers in Dodhi Kh. to also make private investments. Despite this infrastructure, there are frequent crop failures that exacerbate farmer indebtedness caused by wasteful investments (see Table 2). On the other hand, Pandhurli has free access to assured water because of its proximity to Darna River, which allows farmers to have a diverse cropping pattern of food-grain, oilseeds, and seasonal vegetables. Relatively small areas are under orchards because traditional crops continue to be viable. In Wadgaon Sinnar, farmers have a history of intensification along the seasonal Devnadi River. In recent years, farmers pump water from wells in the vicinity of the river to drier farms farther in the village to intensify practice. This coexists with drinking water scarcity in summer for some of its habitations.

A large number of farmers remain outside the cycle of competitive investments and intensification primarily because of socioeconomic constraints. They frequently fall short of irrigation as wells go dry earlier because of excessive investments by others, resulting in poor yields or deintensification. They seek to supplement income through other means such as casual labor. Overall, across all types of farmers, there is loss of faith in the long-term viability of farming and the younger generation aspires to find jobs in the nonfarm sector, which are limited.

\section{Field work conclusion}

We found that farmers have limited access to knowledge in judging the assuredness of their water access and matching it with a viable crop choice, i.e., in farmer decision (a) above. There are multiple sources of variability at play. First is the uncertainty of monsoon, in terms of rainfall amount and intensity, which leads to unplanned irrigation demand and high year-to-year variability in groundwater recharge and availability. Second is the uncertainty in groundwater access due to the high stage of development. The overall water demand is invariably in excess of available resource capacity, and compounded by competitive extraction. Third, there are political limits to informal water transfers because, despite investment in water, there is poor assurance. Finally, there is the variability in market prices. There are agents and networks through which farmers have access to information on new inputs, practices, and financing to implement a selected cropping pattern. But there is no information available, individually or as a community, to ensure that the crop choice is in keeping with the seasonal groundwater availability and irrigation infrastructure. As a result, insufficient irrigation is the most common cause of crop failure and a large number of farmers are burdened with farm loans that they are unable to repay.

At the aggregate level, we found that villages are in transition from one regime of cropping to another. There are "waves" of intensification as new and more remunerative crop varieties get established. New farmer clusters emerge as they find the right combination of geography, infrastructure solution, knowledge consultants, value chain partners, and other social and economic agents to support intensification. Along with them, there is a periphery in which farmers emulate with a delay and with greater risk as one or the other necessary ingredient may be absent and complete information is unavailable.

\section{SYSTEMS MODEL}

As seen above, there are complex human-nature dynamics at play within the SES. We developed a model to understand the feedback mechanisms through which risk propagates in the system and to identify possible points of intervention. Our focal SES is the water-constrained shallow hard-rock aquifer system based on the field area which is representative of large parts of peninsular India. It has two nested levels (Binder et al. 2013). The lower level comprises farming household units and their farmlands. The higher level is the community as a whole within which the available water forms a CPR. There are social, economic, and knowledge agents that influence decisions at both levels. The causal-loop diagram (Sterman 2012) shown in Figure 6 presents the dynamics of farmers' decision making and indicates the trajectory of individual farmers and that of the community.

At the farmer level, the main strategy to counter rising uncertainty in irrigation gives rise to two balancing feedback loops: "Investment to improve access" and "Intensification for profitability." Initially they serve to raise the farmer's access to irrigation relative to others. But the social-learning (Stone 2007) from the success of early movers encourages more farmers to 
follow suit. When this happens, the balancing loops for individual farmers emerge as reinforcing loops for the community as a whole. This is a key outcome of the model. As individual farms intensify, the community irrigation requirement increases leading to a higher stage of groundwater development and increased uncertainty in access for all ("Impact to common property resource" loop). This starts a vicious cycle inducing more farmers to invest and intensify, eroding the advantage of early movers, and causing them to slip in their assurance level ("Competitive investment" loop). The investments are highly inefficient and wasteful as they merely redistribute available water and provide marginal improvement in access until others catch up. Eventually, despite large investments, which drive a thriving horticulture agroeconomy in the region, farmers end up with high risk, large debts and greater inequity in access to ecological services. Indebtedness thus becomes an outcome of competitive investments and intensification, as well as a driver of the vicious cycle of vulnerability (Taylor 2013, Ramprasad 2019), further fed by other social realities and farmers' life events.

\section{A tragedy of the commons or worse?}

The problem of collective action observed in the SES appears to be a typical tragedy of the commons challenge (Hardin 1968) where each agent maximizes appropriation of the CPR so that ultimately everyone is worse off. A study of the farmer payoffs from investments shows that what is unfolding is, in fact, more perverse than the regular formulation (Ostrom 1990). One, in our situation, farmers are not equipped to accurately estimate the amount and duration of available groundwater. Even when the extraction is significantly below the carrying capacity of an "average" rainfall year, a bad drought year causes the system to tip over its carrying capacity (Sterman 2012), initiating the dynamics of competitive investment, leading to high risk even in good rainfall years. Two, the average payoff from investments is initially significant and provides temporary relief from failure because there is a socioeconomic barrier for many to immediately change their strategy and invest. The "follower" farmers invest with a delay when the payoffs have fallen further. Third, when a large number of farmers have made investments and the system has reverted to high risk, a new cash crop higher in the crop hierarchy presents once again the option of escalation by further investments, replaying the earlier dynamics. Such escalation ("Intensification for profitability" loop) stops when the cost of water becomes so high that it exceeds the market value of the output, thereby negating farm profitability (as seen in Fig. 6). This inordinately raises the point of rent dissipation (Ostrom 1990) and explains the economic viability of wasteful investments such as groundwater-filled farm-ponds.

\section{Leverage points}

The systems analysis allows us to evaluate leverage points within the SES (Meadows 1999), i.e., sites of intervention for maximum impact. Figure 7 shows the impact of current government initiatives, which include, on the one hand, creation of water conservation structures, and on the other, subsidy to encourage farm-ponds and horticulture. In the absence of carrying capacity assessment and mechanisms for regulation, these are not only insufficient in stopping the cycle, but are instead likely to increase risk by prompting further intensification.

The key objective must be to achieve a level of intensification within the biophysical and socioeconomic thresholds of the SES.
At the community level, the resource boundary-the available groundwater resource in any season-must be computed, and legitimized within the community. This is a necessary condition to start the process of community negotiations and cooperation to develop rules for deciding farmer-level resource entitlements in terms of viable cropping pattern choices. For example, in a drought year, the community may decide not to cultivate any irrigated crops and instead save water for domestic use and livestock; in another less-than-average rainfall year, it may decide to cultivate only food-grains and low water-intensive horticulture; and overall, it may decide to reduce the fixed water demand by not cultivating any orchards or water-intensive crops such as sugarcane. Figure 7 indicates the location of this leverage point within the vicious cycles. This will not only result in greater sustainability and resilience, but also increase profitability by reducing crop failures and investment costs thereby paving the way for sustainable intensification.

For the above to happen, computation of the seasonal resource envelope at the community level and corresponding farm-level intensification limit is a critical task. This entails mapping of local geohydrology, installing rain-gauges, processes to measure rainfall by the community, and creating local thumb-rules, equivalent to a community water budget, that can relate current year rainfall pattern to available groundwater stock and viable cropping choices. To develop this, there needs to be a practical and local science of water, coproduced by scientists, state agencies, local institutions, and the community, which increases the social comprehension of the SES thresholds and the risk of operating close to them. For state programs, such a water budget could be a key device to address the community as a whole, rather than as a loose collection of individual beneficiaries. This will encourage cooperation instead of competition.

The analysis also points to a still higher point of leverage, one that would change the paradigm of current dynamics, and that is to reverse the crop hierarchy by changing consumer preferences such that they value low water footprint produce. This would align healthy farm incomes with sustainable farming practice.

\section{CONCLUSION}

We found that the shift toward horticulture in water scarce regions is driven by increasing farmer vulnerability caused primarily by uncertainty in water access. Increasing variability due to changing monsoon patterns, high stages of groundwater development, and large competitive investments makes it difficult to accurately estimate the available groundwater and a suitable cropping pattern match. This leads to shortage of water and loss in crop yields. Unable to rely on their traditional crops, farmers are thus induced to make private investments in water infrastructure and intensify even when they are ill-prepared for it. This is often possible only by taking large loans. Because of the CPR property of groundwater, this intensification by some creates a vicious cycle that reinforces risk for the community, further driving new investments and polarizing access to ecological services, including drinking water. The shift to horticulture, although promises greater return on average, also comes with high variability in yields and market returns. As a result, competitive investments and intensification lead to farmer indebtedness and a vicious cycle of increasing vulnerability. Meanwhile, the larger agro-economy of the region, driven by increasing agri-business transactions amongst a large number of economic agents supporting 
intensification, continues to flourish. This endorses the narrative of horticulture as a pathway to greater agricultural productivity, even as farmers bear a large burden of the risk.

We found that the current state interventions are insufficient in stopping the vicious cycles at play and, in fact, promote more competition for water. State watershed interventions are important in enhancing water availability. However, the key goal is to limit intensification to a level that lies within the dynamic biophysical and socioeconomic thresholds of the SES. This will allow for a high intensification level in good rainfall years and deintensification in water scarce years. The ability to dynamically modify the level of intensification based on the resource envelope necessarily implies a reduction in multiyear horticulture crops such as fruit orchards. A crucial task to achieve sustainable intensification is the computation of spatial and seasonal groundwater stock and its mapping to farm level cropping pattern choices. To enable this, we call for the coproduction of a local and relevant science of water through collaboration between scientists, state, and the community. This is a necessary, though not sufficient, condition to enable collective action and regulation. For the farmer, this will make intensification a choice, even a profitable one, and not a forced path of ever-increasing risk. There are villages (Pangare and Pangare 1992, Foster et al. 2009, Das and Burke 2013, Gadgil and Rathore 2015) that have followed such a trajectory. They have demonstrated that with explicit knowledge of their local surface and groundwater dynamics, sustainable levels of seasonal intensification can be agreed upon and regulated by the community while ensuring prosperity and justice in access to the resource. This is a concrete objective to aim for.

Responses to this article can be read online at: http://www.ecologyandsociety.org/issues/responses. $\mathrm{php} / 11825$

\section{Acknowledgments:}

This paper is dedicated to the memory of late Shri Sunil Pote, founder and executive director of Sinnar based NGO Yuva Mitra, whose support and helpful discussions made this research possible. We thank Om P. Damani for his guidance on the systems model. We are grateful to the Maharashtra government's Project on Climate Resilient Agriculture (PoCRA), for which IIT Bombay is a knowledge partner for water management, for their support and implementation of some of our recommendations based on this work.

\section{Data Availability:}

All relevant data that supports this study is included in the manuscript in figures and appendices.

\section{LITERATURE CITED}

Aga, A. 2018. Merchants of knowledge: petty retail and differentiation without consolidation among farmers in Maharashtra, India. Journal of Agrarian Change 18(3):658-676. https://doi.org/10.1111/joac.12249
Anderies, J. M., M. A. Janssen, and E. Ostrom. 2004. A framework to analyze the robustness of social-ecological systems from an institutional perspective. Ecology and Society 9(1):18. https://doi. org/10.5751/ES-00610-090118

Aragona, F. B., and B. Orr. 2011. Agricultural intensification, monocultures, and economic failure: the case of onion production in the Tipajara Watershed on the eastern slope of the Bolivian Andes. Journal of Sustainable Agriculture 35(5):467-492. https:// doi.org/10.1080/10440046.2011.579832

Binder, C. R., J. Hinkel, P. W. G. Bots, and C. Pahl-Wostl. 2013. Comparison of frameworks for analyzing social-ecological systems. Ecology and Society 18(4):26. https://doi.org/10.5751/ ES-05551-180426

Birthal, P. S., P. K. Joshi, S. Chauhan, and H. Singh. 2008. Can horticulture revitalise agricultural growth? Indian Journal of Agricultural Economics 63(3):310-321.

Boserup, E. 1965. The conditions of agricultural growth: the economics of agrarian change under population pressure. George Allen and Unwin, London, UK.

Chand, R. 2017. Doubling farmers' income: rational, strategy, prospects and action plan. National Institute for Transforming India, Government of India, New Delhi, India. [online] URL: http://agricoop.nic.in/sites/default/files/NITI $\% 20$ Aayog $\% 20$ Policy $\%$ 20Paper.pdf

Chatalova, L., D. Müller, V. Valentinov, and A. Balmann. 2016. The rise of the food risk society and the changing nature of the technological treadmill. Sustainability 8(6):584. https://doi. org/10.3390/su8060584

Cochrane, W. W. 1958. Farm prices: myth and reality. University of Minnesota Press, Minneapolis, Minnesota, USA.

Das, S. V., and J. Burke. 2013. Smallholders and sustainable wells: a retrospect: participatory groundwater management in Andhra Pradesh (India). Food and Agricultural Organization of the United Nations, Rome, Italy. [online] URL: http://www.fao.org/3/ i3320e/i3320e.pdf

Foster, S. 2012. Hard-rock aquifers in tropical regions: using science to inform development and management policy. Hydrogeology Journal 20:659-672. https://doi.org/10.1007/ s10040-011-0828-9

Foster, S., S. Limaye, Y. Mandavkar, and S. Msangi. 2009. A hydrogeologic and socioeconomic evaluation of community-based groundwater resource management - the case of Hivre Bazaar in Maharashtra-India. GW-MATE Case Profile Collection 22. World Bank, Washington D.C., USA. [online] URL: http:// documents.worldbank.org/curated/en/858661468041409147/ pdf/518270BRI0Box31BLIC10GWMATE1CP122HB.pdf

Gadgil, M., and C. S. Rathore. 2015. Current status and management of scientific information relating to Indian environment. Proceedings of the Indian National Science Academy 81(5):1087-1112. https://doi.org/10.16943/ptinsa/2015/v81i5/48344

Godfray, H. C. J., and T. Garnett. 2014. Food security and sustainable intensification. Philosophical Transactions of the Royal Society B 369(1639):20120273. https://doi.org/10.1098/ rstb.2012.0273 
Government of India (GoI). 2014a. Ground water information, Nashik District, Maharashtra. Central Groundwater Board, Ministry of Water Resources, Government of India, New Delhi, India. [online] URL: http://cgwb.gov.in/district_profile/maharashtra/ nashik.pdf

Government of India (GoI). 2014b. District Census Handbook Nashik - village and town wise primary census abstract, Series 28 Part XII-B, Census of India 2011. Directorate of Census Operations Maharashtra, Office of the Registrar General \& Census Commissioner, Ministry of Home Affairs, New Delhi, India. [online] URL: https://censusindia.gov.in/2011census/ dchb/2720 PART B DCHB NASHIK.pdf

Government of India (GoI). 2015. All India report on agriculture census 2010-11. Ministry of Agriculture and Farmers' Welfare, Government of India, New Delhi, India. [online] URL: http:// agcensus.nic.in/document/ac1011/reports/air2010-11complete.pdf

Government of India (GoI). 2017a. Report of the committee for doubling farmers' income: Vol VIII: production enhancement through productivity gains. Ministry of Agriculture and Farmers' Welfare, Government of India, New Delhi, India. [online] URL: http://farmer.gov.in/imagedefault/DFI/DFI\%20Vol-8C.pdf

Government of India (GoI). 2017b. Horticultural statistics at a glance 2017. Ministry of Agriculture and Farmers' Welfare, Government of India, New Delhi, India. [online] URL: http:// nhb.gov.in/statistics/Publication/Horticulture $\% 20 \mathrm{At} \% 20 \mathrm{a} \% 20$ Glance $\%$ 202017\%20for $\% 20$ net $\% 20$ uplod $\% 20$ (2).pdf

Government of India (GoI). 2017c. Agricultural statistics at a glance 2017. Ministry of Agriculture and Farmers' Welfare, Government of India, New Delhi, India. [online] URL: https:// eands.dacnet.nic.in/PDF/Agricultural $\% 20$ Statistics $\% 20 \mathrm{at} \% 20 \mathrm{a} \%$ 20Glance $\% 202017$.pdf

Government of Maharashtra (GoM). 2018. Maharashtra groundwater (development \& management) draft rules 2018. Groundwater Survey and Development Authority, Government of Maharashtra, India. [online] URL: https://gsda.maharashtra. gov.in/english/admin/PDF Files/1533615572 Maharashtra Groundwater_Rules_2018.pdf

Hardin, G. 1968. The tragedy of the commons. Science 162 (3859):1243-1248.

Jurriëns, M., P. P. Mollinga, and P. Wester. 1996. Scarcity by design: protective irrigation in India and Pakistan. International Institute for Land Reclamation and Improvement, Wageningen University, Wageningen, The Netherlands. [online] URL: $\underline{\text { https:// }}$ research.wur.nl/en/publications/scarcity-by-design-protective-irrigationin-india-and-pakistan-2

Kale, E. 2017. Problematic uses and practices of farm ponds in Maharashtra. Economic \& Political Weekly 52(3):20-22.

Kulkarni, H., M. Shah, and P. S. V. Shankar. 2015. Shaping the contours of groundwater governance in India. Journal of Hydrology: Regional Studies 4:172-192. https://doi.org/10.1016/j. ejrh.2014.11.004

Matson, P. A., W. J. Parton, A. G. Power, and M. J. Swift. 1997. Agricultural intensification and ecosystem properties. Science 277:504-509. https://doi.org/10.1126/science.277.5325.504
Meadows, D. 1999. Leverage points: places to intervene in a system. Sustainability Institute, Hartland, Vermont, USA. [online] URL: https://www.bfi.org/sites/default/files/attachments/pages/

PlacesInterveneSystem-Meadows.pdf

Meyfroidt, P., R. R. Chowdhury, A. de Bremond, E. C. Ellis, K. H. Erb, T. Filatova, R. D. Garrett, J. M. Grove, A. Heinimann, T. Kuemmerle, C. A. Kull, E. F. Lambin, Y. Landon, Y. le Polain de Waroux, P. Messerli, D. Müller, J. Nielsen, G. D. Peterson, V. Rodriguez García, M. Schlüter, B. L. Turner, and P. H. Verburg. 2018. Middle-range theories of land system change. Global Environmental Change 53:52-67. https://doi.org/10.1016/j. gloenvcha.2018.08.006

Nadkarni, M. V. 2018. Crisis in Indian agriculture. Economic \& Political Weekly 53(17):28-34.

Ostrom, E. 1990. Governing the commons: the evolution of institutions for collective action. Cambridge University Press, Cambridge, UK.

Pangare, G., and V. Pangare. 1992. From poverty to plenty: the story of Ralegan Siddhi. Indian National Trust for Art and Cultural Heritage, New Delhi, India.

Pretty, J., and Z. P. Bharucha. 2014. Sustainable intensification in agricultural systems. Annals of Botany 114(8):1571-1596. https:// doi.org/10.1093/aob/mcu205

Ramprasad, V. 2019. Debt and vulnerability: indebtedness , institutions and smallholder agriculture in South India. Journal of Peasant Studies 46(6):1286-1307. https://doi.org/10.1080/03066150.2018 .1460597

Rasmussen, L. V., B. Coolsaet, A. Martin, O. Mertz, U. Pascual, E. Corbera, N. Dawson, J. A. Fisher, P. Franks, and C. M. Ryan. 2018. Social-ecological outcomes of agricultural intensification. Nature Sustainability 1:275-282. https://doi.org/10.1038/ $\underline{\text { s41893-018-0070-8 }}$

Reddy, D. N., and S. Mishra. 2010. Agrarian crisis in India. Oxford University Press, Oxford, UK. https://doi.org/10.1093/acprof: oso/9780198069096.001.0001

Rockström, J., J. Williams, G. Daily, A. Noble, N. Matthews, L. Gordon, H. Wetterstrand, F. DeClerck, M. Shah, P. Steduto, C. de Fraiture, N. Hatibu, O. Unver, J. Bird, L. Sibanda, and J. Smith. 2017. Sustainable intensification of agriculture for human prosperity and global sustainability. Ambio 46(1):4-17. https:// doi.org/10.1007/s13280-016-0793-6

Scott, J. 1976. The moral economy of the peasant. Yale University, New Haven, Connecticut, USA.

Shah, M. 2013. Water: towards a paradigm shift in the twelfth plan. Economic and Political Weekly 48(3):40-52.

Shah, M. 2016. A 21 st century institutional architecture for India's water reforms. Report submitted by the Committee on Restructuring the CWC and CGWB. Ministry of Water Resources, Government of India, New Delhi, India. [online] URL: http://mowr.gov.in/sites/default/files/Report_on_Restructuring CWC CGWB 0.pdf

Shah, T. 2012. Community response to aquifer development: distinct patterns in India's alluvial and hard rock aquifer areas. 
Shankari, U. 2018. Agrarian crisis: a ringside view - I. Economic \& Political Weekly 53(7):69-77.

Shaver, I., A. Chain-Guadarrama, K. A. Cleary, A. Sanfiorenzo, R. J. Santiago-García, B. Finegan, L. Hormel, N. Sibelet, L. A. Vierling, N. A. Bosque-Pérez, F. DeClerck, M. E. Fagan, and L. P. Waits. 2015. Coupled social and ecological outcomes of agricultural intensification in Costa Rica and the future of biodiversity conservation in tropical agricultural regions. Global Environmental Change 32:74-86. https://doi.org/10.1016/j. gloenvcha.2015.02.006

Singh, D., M. Tsiang, B. Rajaratnam, and N. S. Diffenbaugh. 2014. Observed changes in extreme wet and dry spells during the South Asian summer monsoon season. Nature Climate Change 4:456-461. https://doi.org/10.1038/nclimate2208

Sterman, J. D. 2012. Sustaining sustainability: creating a systems science in a fragmented academy and polarized world. Pages 21-58 in M. P. Weinstein and R. E. Turner, editors. Sustainability science: the emerging paradigm and the urban environment. Springer, New York, New York, USA. https://doi.org/10.1007/978-1-4614-3188-6 2

Stojanovic, T., H. McNae, P. Tett, T. W. Potts, J. Reis, H. D. Smith, and I. Dillingham. 2016. The "social" aspect of social-ecological systems: a critique of analytical frameworks and findings from a multisite study of coastal sustainability. Ecology and Society 21 (3):15. https://doi.org/10.5751/es-08633-210315

Stone, G. D. 2007. Agricultural deskilling and the spread of genetically modified cotton in Warangal. Current Anthropology 48(1):67-103. https://doi.org/10.1086/508689

Suthar, S. K. 2018. Contemporary farmers' protests and the 'new rural - agrarian' in India. Economic and Political Weekly 53:26-27.

Taylor, M. 2013. Liquid debts: credit, groundwater and the social ecology of agrarian distress in Andhra Pradesh, India. Third World Quarterly 34(4):691-709. https://doi.org/10.1080/0143659$\underline{7.2013 .786291}$

Turner, B. L., and A. M. S. Ali. 1996. Induced intensification: agricultural change in Bangladesh with implications for Malthus and Boserup. Proceedings of the National Academy of Sciences 93(25):14984-14991. https://doi.org/10.1073/pnas.93.25.14984

Vasavi, A. R. 2009. Suicides and the making of India's agrarian distress. South African Review of Sociology 40(1):94-108. https:// doi.org/10.1080/21528586.2009.10425102

Villholth, K. G., E. Lopez-Gunn, K. Conti, A. Garrido, and J. Van Der Gun. 2017. Advances in groundwater governance. CRC, London, UK. https://doi.org/10.1201/9781315210025

Weinberger, K., and T. A. Lumpkin. 2007. Diversification into horticulture and poverty reduction: a research agenda. World Development 35(8):1464-1480. https://doi.org/10.1016/j. worlddev.2007.05.002 
Appendix 1. Geographic visualization of the field area (village boundaries) in KML format to be opened using an Earth browser such as Google Earth 
Appendix 2: Sinnar Rainfall pattern

Figure A2.1. Historical trends (2005 to 2016) of total annual rainfall and number of rainy days in Sinnar

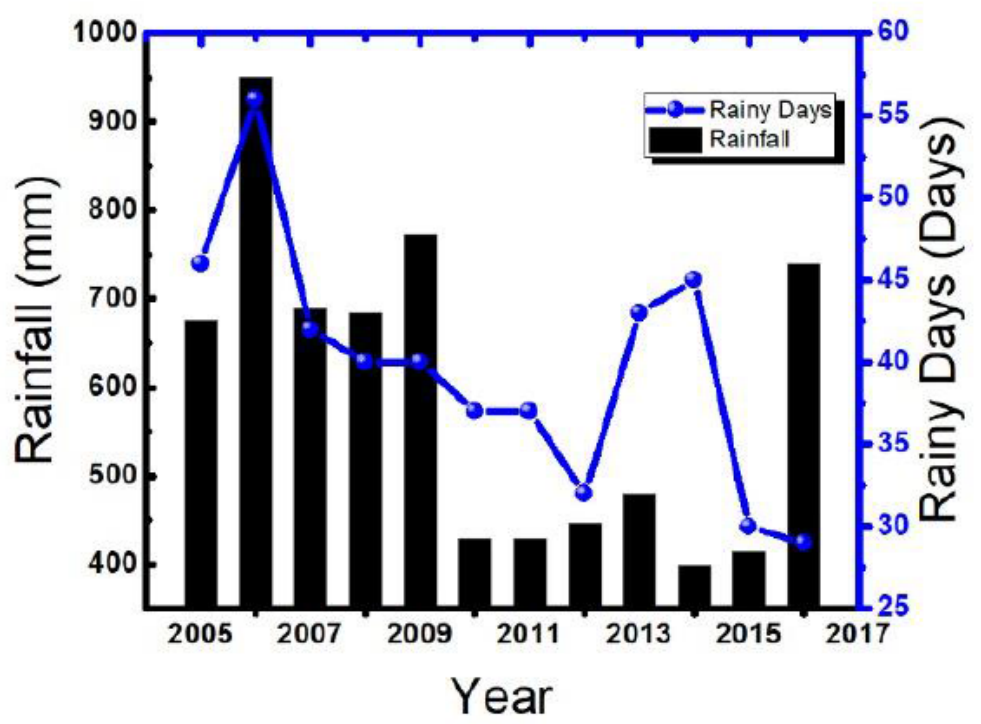

Figure A2.2. Comparison of daily rainfall pattern of 2015 vs 2016. 2015-16 was a bad drought year (494mm rainfall) due to the cumulative effect of consecutive droughts in preceding years. In contrast, 2016 was a good rainfall year $(739 \mathrm{~mm})$. Dry spells during monsoons were seen in both years. In 2015, there were long dry spells in the beginning of the monsoon when water was already scarce from drought in preceding years while in 2016 the dry spell came after two months of good rainfall hence its impact was lower

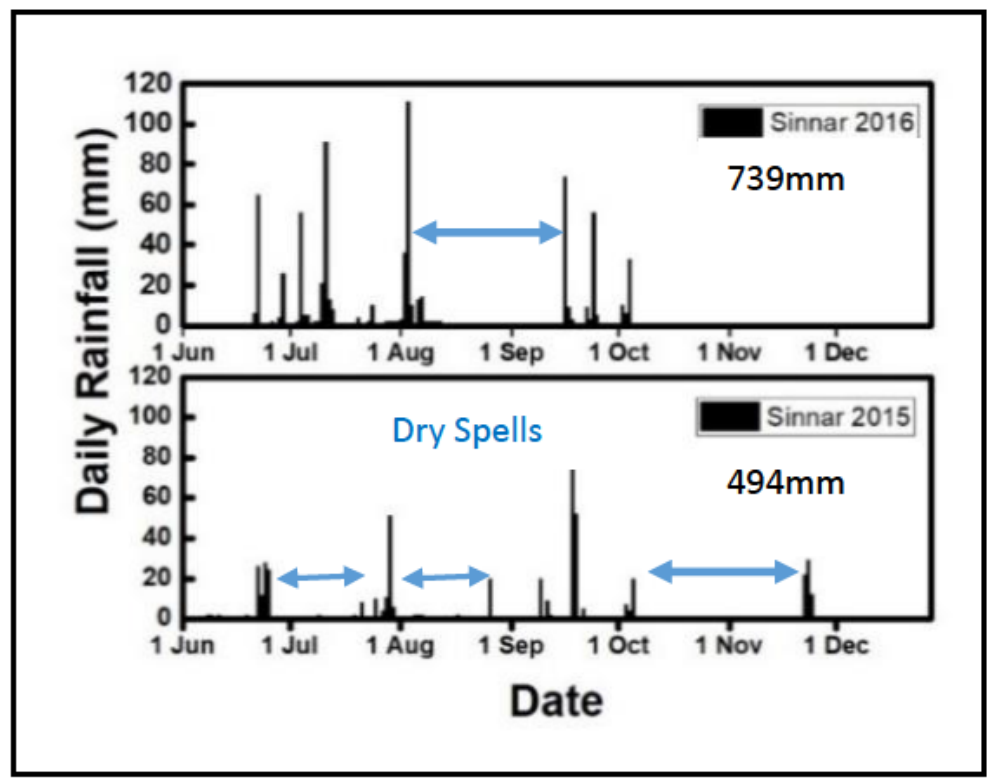


Figure A2.3 Variation of rainfall within Sinnar block as seen from West (high-rainfall region) to East (low rainfall region). The block is divided into seven agricultural circles each of which has a rain-gauge maintained by the agricultural department. Daily rainfall for each circle is available online at http://maharain.gov.in/.

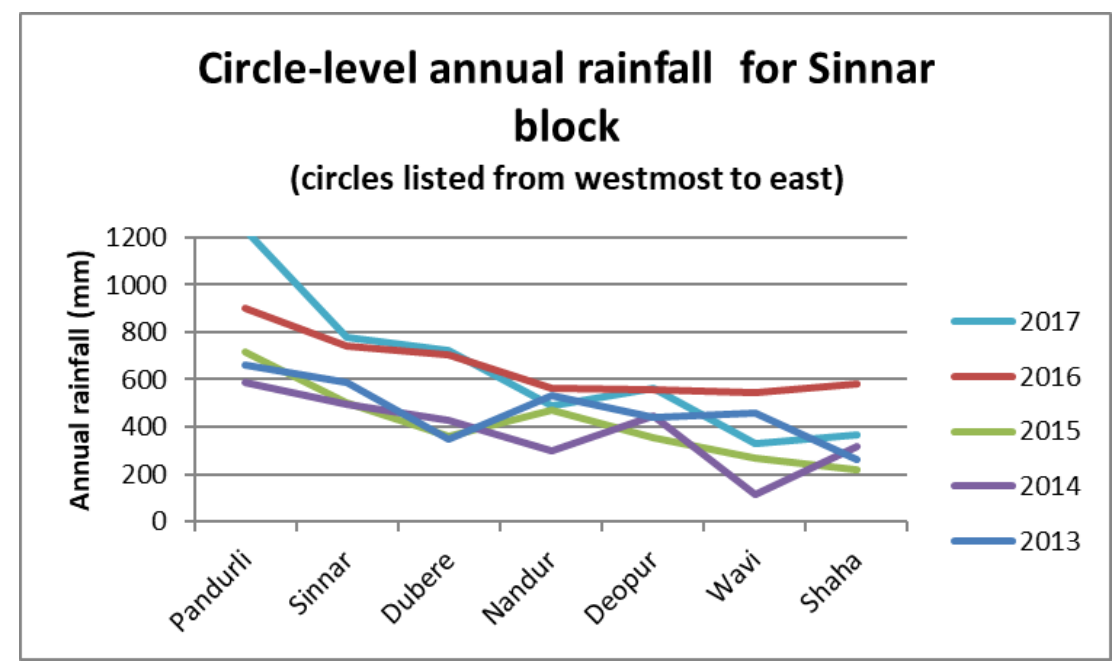


Appendix 3: Survey sample distribution

Table A3.1. Sample distribution by landholding category compared to actual landholding distribution as obtained from respective village revenue offices

\begin{tabular}{lllllllll}
\hline \hline \multirow{2}{*}{$\begin{array}{l}\text { Landholding } \\
\text { (hectares) }\end{array}$} & \multicolumn{2}{c}{ Wadgaon } & \multicolumn{2}{c}{ Dodhi Kh } & \multicolumn{2}{c}{ Dapur } & \multicolumn{2}{c}{ Pandhurli } \\
\cline { 2 - 9 } & Surveyed & Actual & Surveyed & Actual & Surveyed & Actual & Surveyed & Actual \\
farmers & distribution & farmers & distribution & farmers & distribution & farmers & distribution \\
\hline$<1$ & $47 \%$ & $58 \%$ & $31 \%$ & $42 \%$ & $39 \%$ & NA $^{\dagger}$ & $50 \%$ & $55 \%$ \\
1 to 2 & $21 \%$ & $26 \%$ & $50 \%$ & $33 \%$ & $27 \%$ & $\mathrm{NA}^{\dagger}$ & $28 \%$ & $32 \%$ \\
2 to 5 & $26 \%$ & $14 \%$ & $17 \%$ & $22 \%$ & $27 \%$ & $\mathrm{NA}^{\dagger}$ & $11 \%$ & $11 \%$ \\
$>5$ & $6 \%$ & $2 \%$ & $3 \%$ & $3 \%$ & $6 \%$ & $\mathrm{NA}^{\dagger}$ & $11 \%$ & $2 \%$ \\
\hline Total count & $\mathrm{n}=34$ & 582 & $\mathrm{n}=36$ & 546 & $\mathrm{n}=33$ & 1549 & $\mathrm{n}=18$ & 691 \\
\hline
\end{tabular}

$\uparrow$ Data could not be obtained from village revenue office 
Appendix 4: Mean and standard deviation of wholesale market rate for main crops

Table A4.1. The agricultural wholesale market rates are published as (Min rate, Modal rate, Max rate) each day for all crops of a market yard. The \% standard deviation column of the model price indicates the variation in the modal rate from day to day. It shows that the variation in the daily modal rate is significantly higher for horticulture produce than for non-perishable produce. The difference between the min rate of the day and the max rate for the day gives the price spread for any day. These variations are typically caused due to a difference in quality of the produce. This spread is also higher for perishable crops compared to foodgrain and oilseeds.

\begin{tabular}{lllll}
\hline Crop & $\begin{array}{l}\text { Cultivation } \\
\text { season }\end{array}$ & $\begin{array}{l}\text { Average modal } \\
\text { Nashik wholesale } \\
\text { market rate in }\end{array}$ & $\begin{array}{l}\text { Standard deviation } \\
\text { of modal price } \\
\text { distribution in } \\
\text { (Rs/Quintal) }\end{array}$ & $\begin{array}{l}\text { Mean price } \\
\text { spread as share } \\
\text { of mean price }\end{array}$ \\
\hline Pearl Millet & Kharif & 1526.00 & $6 \%$ & \\
Soybean & Kharif & 3662.00 & $4 \%$ & $17 \%$ \\
Maize & Kharif & 1442.00 & $4 \%$ & $7 \%$ \\
Green leafy vegetables & Kharif & 1560.00 & $48 \%$ & $56 \%$ \\
Onion & Kharif & 1193.80 & $31 \%$ & $134 \%$ \\
Tomato & Kharif & 1385.75 & $44 \%$ & $76 \%$ \\
Green gram & Rabi & 4289.00 & $9 \%$ & $16 \%$ \\
Sorghum & Rabi & 1822.0 & $8 \%$ & $3 \%$ \\
Wheat & Rabi & 1666.00 & $12 \%$ & $14 \%$ \\
Onion & Rabi & 622.5 & $19 \%$ & $731 \%$ \\
Tomato & Rabi & 868.21 & $40 \%$ & $114 \%$ \\
Pomegranate & Multi-year & 2889.00 & $64 \%$ & $52 \%$ \\
Grapes & Multi-year & 3644.00 & $50 \%$ & \\
\hline
\end{tabular}


Appendix 5: Comparison of sown area by sampled farmers: 2015 and 2016

Table A5.1 Comparison of seasonal sown area by sampled farmers in 2015 vs 2016 (same sample farmers in both years). In the drought year of 2015-16, large share of cultivable area was left fallow after Kharif cultivation as can be seen by the reduced area under Rabi and Summer. This was highest for Dodhi followed by Dapur. In 2016-17, the fallow land was significantly reduced in response to better rainfall. There was also an increase in multiyear orchards seen most in the two driest villages of Dodhi and Dapur.

\begin{tabular}{|c|c|c|c|c|c|c|c|c|c|}
\hline \multirow[t]{2}{*}{ Village } & \multirow{2}{*}{$\begin{array}{l}\text { Net } \\
\text { cultivable } \\
\text { area (ha) }\end{array}$} & \multicolumn{4}{|c|}{$\begin{array}{l}\text { 2015-16 (bad rainfall year) sown } \\
\text { area by sampled farmers (ha) }\end{array}$} & \multicolumn{4}{|c|}{$\begin{array}{l}\text { 2016-7 (good rainfall year) sown } \\
\text { area by sampled farmers (ha) }\end{array}$} \\
\hline & & Kharif & Rabi & Summer & MY & Kharif & Rabi & Summer & MY \\
\hline Dodhi Kh & 834 & 35.1 & 12.0 & 0 & 1.8 & 33.9 & 23.4 & 1.2 & 3.2 \\
\hline Dapur & 1320 & 34.3 & 16.8 & 0 & 12.3 & 35.0 & 24.6 & 1.9 & 15.8 \\
\hline Wadgaon Sinnar & 693 & 27.3 & 18.0 & 0.2 & 2.4 & 27.8 & 24.5 & 4.8 & 2.6 \\
\hline Pandhurli & 866 & 22.6 & 21.2 & 1.4 & 5.2 & 24.9 & 23.4 & 9.4 & 5.2 \\
\hline
\end{tabular}


Appendix 6. Data of 121 interviewed farmers in MS Excel format. Brief description of farmer trajectory in terms of history of investments and intensification or de-intensification decisions

Please click here to download file 'appendix6.xlsx'. 